\title{
Prehospital Use of Herbal Medicine in the Southwestern Ethiopia: Prevalence, Associated Factors and Safety Concern
}

\author{
Alemneh Mengie \\ Jimma University \\ Gemmechu Hasen ( $\sim$ gemmechuhasen2009@gmail.com ) \\ Jimma University \\ Sultan Suleman \\ Jimma University
}

\section{Research Article}

Keywords: Prehospital, Herbal medicine, Use, Patients, Ethiopia

Posted Date: November 30th, 2021

DOI: https://doi.org/10.21203/rs.3.rs-1077391/v1

License: (c) (i) This work is licensed under a Creative Commons Attribution 4.0 International License.

Read Full License 


\section{Abstract \\ Background}

In Ethiopia, despite the frequent reports that demonstrate the use of herbal medicine for treatment of many ailments, there is no finding that describes the prevalence and associated factors with prehospital use of herbal medicine. Therefore, the present study was aimed to assess the prevalence of the prehospital use of herbal medicine and associated factors as well as safety concern in the South western Ethiopia.

\section{Methodology:}

A Hospital based cross-sectional study design was employed among patients admitted to Medical wards in Jimma Medical Center (JMC) $(n=217)$ from June to September, 2021. The pre-tested questionnaire was used for data collection. Moreover, literatures were reviewed to identity the potential toxicity and/or drug interactions (if any,) associated with the herbal medicine used before admission by patients. The Statistical Package for Social Science (SPSS) version 21.0 (Chicago, SPSS Inc.) was used for data analysis. The results were summarized using descriptive statistics. The bivariate logistic regression was used to check the association between the outcomes and independent variables. Then, multivariate logistic regression was employed for independent variables possessing $p$-value of less than 0.05 to identify the strength of association between variables at $5 \%$ level of significance.

\section{Results}

The current study revealed that about $34 \%$ of respondents revealed the prehospital use of herbal medicine. The majority respondents (78.7\%) did not discuss with their health care providers about prehospital use of herbal medicine. The factors like age (AOR: $0.281,95 \% \mathrm{Cl}: 0.115,0.683$ ), educational level (AOR: 2.672, 95\% Cl: 1.101, 6.485) and insurance coverage (AOR: 2.082, 95\% Cl: 1.083, 4.004) were significantly associated with prehospital use of herbal medicine. Moreover, 'Dammakese' (Ocimum gratissimum L), 'Tenadam' (Ruta chalepensis L), 'Makkanisa' (Croton macrostachyus), 'Jinjibli' (Zingiber officinale), 'Barzaafi Adii' (Eucalyptus globulus Labill), 'Qabarichoo' (Echinops kebericho, Mesfin) and 'Papaya' (Carica papaya L) were the most commonly used herbs before admission to hospital. From published literatures review we revealed that the Zingiber officinale, Carica papaya L, Eucalyptus globulus Labill and Ruta chalepensis $L$ possess the potential interaction with many conventional medicines as well as toxic effects.

\section{Conclusions}


The present study revealed that the prehospital use of herbal medicine was relatively high in which majority of patients did not disclose to the health care providers. Its use was significantly associated with age, educational level and insurance coverage. In addition, some of herbs used are associated with safety issues. Therefore, health care providers should thoroughly discuss with their patients regarding the prehospital use of herbal medicine.

\section{Introduction}

Herbal medicine is defined as herbs, herbal materials, herbal preparations, and finished herbal products, that contain active ingredient in parts of the plants, or plant materials, or combinations thereof to treat, diagnose, prevent illness and maintain well-being (1). It is a mixture of various organic chemicals derived from raw or processed sections of plants, including leaves, flowers, stems, seeds, and roots (2).Globally, the herbal medicines have been used as a source of medicine, and $80-85 \%$ of populations rely on these medicinal plants using the extracts or their active components as a traditional medicine to meet their primary health care needs (3-5).

Over last few decades, the use of herbal medicine has been increased especially in developing countries including Ethiopia (6-9). This resurgence of public interest in herbal medicine has been linked to a number of factors particularly, the various claims on the efficacy or effectiveness of plant medicines, the consumer choice for natural remedies and greater interest for alternative medicine, the misconception that herbal products are superior to synthetic products, the belief that herbal remedies may be effective in treating certain ailments that have proved to be ineffective or inadequate with conventional drugs, the high cost and side effects of most modern drugs, the patients' beliefs that their health care professionals do not accurately identify the problem; so they feel that herbal remedies are an alternative, and a move to self-medication (10-13). These claims and perceptions have amplified the continued use of herbal medicines among consumers, even concomitantly with modern medicines despite the potential harmful drug interactions with collective undesirable effects of increased toxicity and decreased efficacy (14-19). Moreover, in recent years, the evidence of pre-admission use of herbal medicine among patients have been reported in previous literatures, and revealed that the prehospital use of herbal medicine was associated with high risk developing a hospital-acquired suspected adverse drug reaction, delay of hospitalization, the occurrence of toxicity (20-23). Simultaneously, the patients often do not disclose prehospital use of herbal medicine to their physicians (24-31) that could affect patients treatment outcomes. However, in Ethiopia, despite frequent reports that demonstrate the use of herbal medicine for treatment of many ailments $(24,32-34)$, there is no finding that describes the prehospital use of herbal medicine and associated factors. Moreover, the very recent finding has evidenced the need of comprehensive study on prehospital use of herbal medicine among consumers (35). Therefore, it was hypothesized that there would be a prehospital use herbal medicine in Ethiopia, particularly in the early stages to alleviate symptoms of fever, common cold, chilling, headache and malaria related symptoms as the southwestern region is very malarias (36). Therefore, the present study was aimed to assess the prevalence of the prehospital use of herbal medicine and associated factors as well as safety concern in the South western Ethiopia. 


\section{Methodology}

\section{Study design, period and location}

A Hospital based cross-sectional study design was employed among patients admitted to Medical wards in Jimma Medical Center (JMC) ( $\mathrm{n}=217)$ from June to September, 2021.Jimma Medical Center is located in Jimma Town, and $350 \mathrm{~km}$ away from Addis Ababa, the capital of Ethiopia. It provides the major services encompassing nine medical, clinical, and diagnostic departments. Approximately, 15,000 inpatients and 160,000 out patients, 11,000 emergency cases, and 4,500 deliveries came to the center in year from catchment population of about 15 million (37).

\section{Sample population, size, and sampling technique}

The minimum sample size was calculated using Raosoft sample size calculator (38). As such, a sample size contained of 234 patients was calculated by considering a $5 \%$ margin of error, $95 \%$ confidence interval, and $50 \%$ distribution response for an approximate population of 600 (the total patients expected to be admitted to Medical wards of JMC during period of one month) (39). Including the $5 \%$ dropouts, 245 participants were included in the study. All adult patients aged 18 years or older admitted to medical wards and who provided a written informed consent were allowed to participate in the study while unconscious patients and those who refused to give the consent were excluded from the study.

\section{Data collection tool and procedure}

The data collection tool was developed based extensive review of previous literature articles $(4,12,16,40)$. It was firstly prepared in English, and was translated to local languages (Afaan Oromo and Amharic) and reversed back to English for the purpose of consistency by languages experts. Moreover, four experts have examined the face validity and as well as readability of the questionnaire, paying attentions on easy comprehension of the questionnaire to gear to general populations. Before commencement of the actual study, the pre-test was conducted on $5 \%$ of populations to check acceptability and consistency of data collection tool. The questionnaire has two sections; the first section was designed to assess the sociodemographic characteristic of the patients while the second section was used to dig information regarding the pre-hospital use of herbal medicine among patients. Moreover, literatures were reviewed to identity the potential toxicity and/or drug interactions (if any,) associated with the herbal medicine used before admission by patients.

\section{Statistical analysis}

All the filled questionnaires were checked to ensure their completeness before they were manually entered into the Statistical Package for Social Science (SPSS) version 21.0 (Chicago, SPSS Inc.) after appropriate coding for analysis. The results were summarized using descriptive statistics. The bivariate logistic regression was used to check the association between the outcomes (status of pre-hospital use of herbal medicine) and independent variables (Gender, age, marital, educational, occupation, residence, monthly income, insurance coverage).Then, multivariate logistic regression was employed for independent 
variables possessing $p$-value of less than 0.05 to identify the strength of association between variables at $5 \%$ level of significance.

\section{Results}

\section{Sociodemographic characteristics of study participants}

Two hundred seventeen (217) study participants responded in this study from 245 sample size, yielding $88.5 \%$ response rate. Among study participants, the majority of respondents $(n=115,53 \%)$ were males and age grouped greater than 50 years old $(n=61,28.1 \%)$. About $80.2 \%$ of study participants were married, and the majority $(n=64,29.5 \%)$ of them categorised under secondary school stage of educational status. With regard to occupation, the majority of respondents $(n=79,36.4 \%)$ were farmers, and more than half of respondents $(n=121,55.8 \%)$ were readmitted. Moreover, around $57 \%$ of study participants were from a rural area, and about $28.2 \%$ of respondents had a monthly income was below 1500 Ethiopian Birr (Table 1).

\section{Table 1: Socio demographic characteristics of the respondents}




\begin{tabular}{|c|c|c|}
\hline Variables & Frequency $(n=217)$ & Percentage (\%) \\
\hline \multicolumn{3}{|l|}{ Gender } \\
\hline Male & 115 & 53.0 \\
\hline Female & 102 & 47.0 \\
\hline \multicolumn{3}{|l|}{ Age } \\
\hline $18-29$ & 58 & 26.7 \\
\hline $30-39$ & 54 & 24.9 \\
\hline $40-49$ & 44 & 20.3 \\
\hline$\geq 50$ & 61 & 28.1 \\
\hline \multicolumn{3}{|l|}{ Marital Status } \\
\hline Single & 31 & 14.3 \\
\hline Married & 174 & 80.2 \\
\hline Divorced & 12 & 5.5 \\
\hline \multicolumn{3}{|l|}{ Educational status } \\
\hline No formal education & 47 & 21.7 \\
\hline Primary school & 54 & 24.9 \\
\hline Secondary school & 64 & 29.5 \\
\hline College/Diploma & 35 & 16.1 \\
\hline Degree and above & 17 & 7.8 \\
\hline \multicolumn{3}{|l|}{ Occupation } \\
\hline Government Employee & 46 & 21.2 \\
\hline Private Employee & 52 & 24.0 \\
\hline Farmer & 79 & 36.4 \\
\hline Daily Labor & 30 & 13.8 \\
\hline Others & 10 & 4.6 \\
\hline \multicolumn{3}{|l|}{ Residence } \\
\hline Urban & 92 & 42.4 \\
\hline Rural & 125 & 57.6 \\
\hline Monthly income & & \\
\hline
\end{tabular}




\begin{tabular}{|lll|}
\hline$<1500$ ETB & 83 & 38.2 \\
\hline 1500-2500 ETB & 65 & 30.0 \\
\hline 2500 ETB & 69 & 31.8 \\
\hline Insurance coverage & \\
\hline Yes & 107 & 49.3 \\
\hline No & 110 & 50.7 \\
\hline Admission history of the patient & & \\
\hline New admission & 96 & 44.2 \\
\hline Readmission & 121 & 55.8 \\
\hline
\end{tabular}

Abbreviation: ETB, Ethiopian Birr

\section{Prevalence and characteristics of prehospital use of herbal medicine}

About $34 \%$ of respondents reported their prehospital use herbal medicine (Figure 1). Among users of herbal medicine before admission, about $17.3 \%$ of respondents experienced side effects after having of herbal medicine thus about $8 \%$ of them dissatisfied with their use while $13.3 \%$ became neutral. The majority of respondents $(n=62,85.2 \%)$ and $(n=59,78.7 \%)$ did not discuss with their health care providers about prehospital use of herbal medicine, and did not know drug-herb interaction respectively. Moreover, the majority of respondents $(n=34,45.3 \%)$ did get herbal medicine from their home/back yard garden, and about $96 \%$ of them were volunteer to specify types of herbs used (Table 2). The most commonly used herbal medicine reported by respondents were depicted in table 4 with their Local, Scientific,Family name, reason for use and the potential toxicity and/or drug-herb interactions (Table 4).

\section{Factor affecting prehospital use of herbal medicine}

The multivariable logistic regression revealed that age, educational level and insurance coverage were significantly associated with prehospital use of herbal medicine. Accordingly, the patients who aged between 30-39 years old were 71.9 times less likely use herbal medicine than those aged between 18-29 years old (AOR: $0.281,95 \% \mathrm{Cl}: 0.115,0.683)$. Besides, the patients who had educational level of secondary school were 2.672 times more likely use herbal medicine than those who had no formal education(AOR: $2.672,95 \% \mathrm{Cl}: 1.101,6.485)$. Moreover, the patients who had no insurance coverage were 2.082 times more likely use than those who had insurance coverage (AOR: $2.082,95 \% \mathrm{Cl}: 1.083,4.004$ ) (Table 3).

Table 2: Characteristics of prehospital use of herbal medicine 


\begin{tabular}{|c|c|c|}
\hline Items & Frequency $(n=75)$ & $\begin{array}{l}\text { Percentage } \\
(\%)\end{array}$ \\
\hline \multicolumn{3}{|c|}{ How did you satisfy with herbal medicine use before admission? } \\
\hline Satisfied & 24 & 32 \\
\hline Average & 35 & 46.7 \\
\hline Neutral & 10 & 13.3 \\
\hline Dissatisfied & 6 & 8.0 \\
\hline \multicolumn{3}{|c|}{ Experienced any side effect after having herbal medicine } \\
\hline Yes & 13 & 17.3 \\
\hline No & 62 & 82.6 \\
\hline \multicolumn{3}{|c|}{$\begin{array}{l}\text { Discussed with their HCPs about prehospital use of herbal } \\
\text { medicine }\end{array}$} \\
\hline Yes & 11 & 14.6 \\
\hline No & 64 & 85.4 \\
\hline \multicolumn{3}{|c|}{ Do you think there may be drug-herb interaction? } \\
\hline Yes & 16 & 21.3 \\
\hline No & 59 & 78.7 \\
\hline \multicolumn{3}{|c|}{ Volunteer to specify types of herbs used } \\
\hline Yes & 72 & 96.0 \\
\hline No & 3 & 4.0 \\
\hline \multicolumn{3}{|c|}{ Source where did you get the herbal medicine } \\
\hline At home/back yard garden & 34 & 45.3 \\
\hline Traditional healers/Herbalist & 27 & 36.0 \\
\hline Relative/friends & 6 & 8.0 \\
\hline Others & 8 & 10.7 \\
\hline
\end{tabular}

Table 3: Factors associated with prehospital use of herbal medicine 
Prehospital Use of HM

(\%)

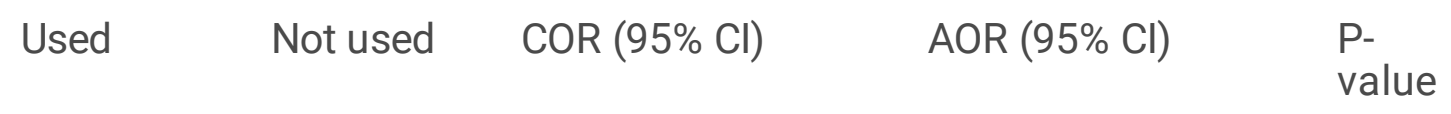

\section{Age category}

$\begin{array}{llllll}18-29 & 13 & 45 & 1 & 0.029 \\ & (22.4 \%) & \begin{array}{l}4 \\ (77.6 \%)\end{array} & & & \\ 30-39 & 25 & 29 & 0.333(0.148, & 0.281(0.115, \\ & (46.3 \%) & (53.7 \%) & 0.758)^{\star} & 0.683)^{\star} \\ 40-49 & 12 & 32 & 0.770(0.311, & 0.719(0.296, \\ & (27.3 \%) & (72.7 \%) & 1.906) & 1.922) \\ \geq 50 & 25 & 36 & 0.416(0.187, & 0.448(0.186 \\ & (41.0 \%) & (59.0 \%) & 0.957)^{*} & 1.079)\end{array}$

\section{Educational status}

No formal

education

Primary school

Secondary school

Certificate/Diploma

Degree and above
19

$(40.4 \%)$

14

(25.9\%)

14

(21.9\%)

21

$(60.0 \%)$

$7(41.2 \%)$
$28(59.6 \%) \quad$ ।

40

$(74.1 \%)$

50

(78.1\%)

14

$(40.0 \%)$

10

$(58.8 \%)$
1.612 (0.699,

3.716)

1.964 (0.847,

4.533)

0.452 (0.191,

1.087)

$0.965(0.338$,

2.751)
I

1.957 (0.779,

4.921)

2.672 (1.101,

$6.485)$ *

0.553 (0.197,

1.546)

1.164 (0.315,

4.299)

\section{Residence}

Urban

40

$(43.5 \%)$

Rural

$$
35
$$

(28.0\%)

$52(56.5 \%) \quad$ ।

90

(72.0\%)
1.978 (1.121,

3.490)

\section{Monthly income}

$\begin{array}{llllll}<1500 \text { ETB } & 21 & 62 & \text { I } & \text { I } & 0.496 \\ & (25.3 \%) & (74.7 \%) & & 0.667(0.324, & 0.642(0.294, \\ 1500-2500 \text { ETB } & 22 & 43 & 1.351) & 1.402) \\ & (38.8 \%) & (66.2 \%) & 0.689(0.300, \\ >2500 \text { ETB } & 32 & 37 & 0.392(0.197, & 0.584)\end{array}$




\begin{tabular}{|llllll|} 
Yes & $44(41.1 \%)$ & $63(58.9 \%)$ & I & 1 & 0.028 \\
No & $31(28.2 \%)$ & $79(71.8 \%$ & $1.819(1.032$, & $2.082(1.083$, \\
& & $3.205)^{*}$ & $4.004)^{*}$ & \\
\hline
\end{tabular}

Note: *Statistically significant at $95 \% \mathrm{Cl}$, Abbreviations: ETB: Ethiopian Birr; $\mathrm{Cl}$, Confidence Interval; COR, Crude Odd Ratio; AOR, Adjusted Odd Ratio.

Table 4: Types of herbal medicines used by participants before admission 


\begin{tabular}{|c|c|c|c|c|c|}
\hline Scientific Name & Family & Local name & Frequency & $\begin{array}{l}\text { Reason for } \\
\text { use }\end{array}$ & $\begin{array}{l}\text { Potential toxicity } \\
\text { and/or drug-herb } \\
\text { interaction }\end{array}$ \\
\hline $\begin{array}{l}\text { Zingiber } \\
\text { officinale }\end{array}$ & Zingiberaceae & Zinjibli & $6(8.3 \%)$ & $\begin{array}{l}\text { GIT } \\
\text { discomfort, } \\
\text { nausea, } \\
\text { vomiting }\end{array}$ & $\begin{array}{l}\text { Interaction } \\
\text { between Ginger- } \\
\text { crizotinib, } \\
\text { anticancer (41), } \\
\text { Z. officinale } \\
\text { losartan, } \\
\text { antihypertensive } \\
\text { have been } \\
\text { indicated (42) }\end{array}$ \\
\hline $\begin{array}{l}\text { Croton } \\
\text { macrostachyus }\end{array}$ & Euphorbiaceae & Makannisa & $12(16.6 \%)$ & $\begin{array}{l}\text { Malaria, } \\
\text { common cold }\end{array}$ & - \\
\hline $\begin{array}{l}\text { Eucalyptus } \\
\text { globulus Labill }\end{array}$ & Myrtaceae & $\begin{array}{l}\text { Barzaafi } \\
\text { adii }\end{array}$ & $5(6.9 \%)$ & $\begin{array}{l}\text { Asthma, } \\
\text { headache, } \\
\text { common } \\
\text { cold }\end{array}$ & $\begin{array}{l}\text { Interaction } \\
\text { between } \\
\text { Eucalyptus } \\
\text { globulus Labill } \\
\text { and diazepam } \\
\text { has been } \\
\text { evidenced in } \\
\text { mice (43) }\end{array}$ \\
\hline $\begin{array}{l}\text { Ocimum } \\
\text { gratissimum L. }\end{array}$ & Lamiaceae & Damakesse & 22 (30.5\%) & $\begin{array}{l}\text { Malaria, } \\
\text { Gastritis }\end{array}$ & - \\
\hline $\begin{array}{l}\text { Ruta } \\
\text { chalepensis L. }\end{array}$ & Rutaceae & Tenadam & 19 (26.3\%) & $\begin{array}{l}\text { Ameobiasis, } \\
\text { stomachache, } \\
\text { fever }\end{array}$ & $\begin{array}{l}\text { Based on dose } \\
\text { the Ruta } \\
\text { chalepensis } L \\
\text { could produce } \\
\text { neurotoxic } \\
\text { effects (44). }\end{array}$ \\
\hline $\begin{array}{l}\text { Carica papaya } \\
\text { L. }\end{array}$ & Caricaceae & Papaya & $4(5.5 \%)$ & $\begin{array}{l}\text { Gastritis, } \\
\text { Giardiasis }\end{array}$ & $\begin{array}{l}\text { Interactions } \\
\text { between C. } \\
\text { papaya leaf with } \\
\text { oral } \\
\text { hypoglycemic } \\
\text { agents } \\
\text { (metformin and } \\
\text { glimepiride), } \\
\text { antimalarial } \\
\text { (artemisinin), } \\
\text { antibiotic } \\
\text { (ciprofloxacin), } \\
\text { and } \\
\text { cardiovascular } \\
\text { drug (digoxin) } \\
\text { have been } \\
\text { evidenced (45) }\end{array}$ \\
\hline $\begin{array}{l}\text { Echinops } \\
\text { kebericho, } \\
\text { Mesfin }\end{array}$ & Asteraceae & Qabarichoo & $4(5.5 \%)$ & $\begin{array}{l}\text { Malaria, } \\
\text { headache, } \\
\text { Gastritis }\end{array}$ & $\begin{array}{l}\text { Evidenced as } \\
\text { well tolerated for } \\
\text { toxicity profile in } \\
\text { rat(46) }\end{array}$ \\
\hline
\end{tabular}




\section{Discussion}

This study reported the first study of its kind in Ethiopia regarding the prehospital use of herbal medicine and associated factors among patients admitted to health facilities. Accordingly, about $34 \%$ of respondents revealed the prehospital use of herbal medicine. This result is higher when compared with study conducted in German (30\%) (29), Canada (27\%) (47), China (13\%) (48), even though it was lower than study conducted in Uganda (79\%) (20), this might be related with employment of different study approach and variations in sample size of study population. The higher prevalence of prehospital use of herbal medicine in our study could be due to the fact that Ethiopia is endowed with rich and diverse flora that comprised a foundation for primary health care $(4,34)$. In addition, theSouthwestern region of Ethiopia, Jimma zone, is very malarias (36) thus patients could use herbal medicine before admission to hospital in the early stages of sickness to alleviate symptoms like fever, common cold, chilling, headache and malaria related symptoms.

In the present study, majority of respondents did not discuss with their health care providers as they have used herbal medicine before admission. This finding is consistent with other studies (24-31), thus it very crucial to elucidate the use of herbal medicine during clinical history taking process (20). In the current study, factors like age, educational level and insurance coverage were significantly associated with prehospital use of herbal medicine. Similar findings have been reported in previous literatures (49).

Moreover, 'Dammakese' (Ocimum gratissimum L), 'Tenadam' (Ruta chalepensis L), 'Makkanisa'(Croton macrostachyus), 'Jinjibli' (Zingiber officinale), 'Barzaafi Adii' (Eucalyptus globulus Labill), 'Qabarichoo' (Echinops kebericho, Mesfin) and 'Papaya' (Carica papaya L) were the most commonly used herbs before admission to hospital. However, despite their benefits, some of these herbs are associated with the potential toxicity and/or drug-herb interactions. For instance, the interactions between Gingercrizotinib (41), Z. officinale-losartan (42), and interactions between C. papaya leaf with oral hypoglycemic agents (metformin and glimepiride), antimalarial (artemisinin), antibiotic (ciprofloxacin), and cardiovascular drug (digoxin) (45) have been reported in literatures. Moreover, the interaction between Eucalyptus globulus Labill and diazepam has been evidenced in mice (43) while the Ruta chalepensis L could produce neurotoxic effects particularly at high doses (44). Even in our study, among users of herbal medicine before admission, about $17.3 \%$ of respondents experienced side effects and more than threefourth of patients did not know drug-herb interactions. Therefore, the prehospital use of herbal medicine without appropriate discussion between patients and health care providers could results in severe health consequences.

\section{Conclusion}

The present study revealed that the prehospital use of herbal medicine was relatively high in which majority of patients did not disclose to the health care providers. Its use was significantly associated with age, educational level and insurance coverage. In addition, some of herbs used are associated with safety 
issues. Therefore, health care providers should thoroughly discuss with their patients regarding the prehospital use of herbal medicine.

\section{Declarations}

\section{Acknowledgements}

The authors would like to extend the heartfelt gratitude to all study respondents for accepting invitation to be involved in this study.

\section{Authors' Contributions}

AM and GH designed, extracted, analysed and interpreted the data. GH and SS conceived the study; guided the design and supervised the whole research. GH also prepared the manuscript. All authors read and approved the final manuscript.

\section{Competing interests}

We declare there are no competing interests.

\section{Availability of data and materials}

The documents supporting this study will be available upon request from corresponding author.

\section{Consent for publication}

Not applicable.

\section{Ethical approval and consent to participate}

The ethical principle outlined in the Helsinki Declaration was followed for this study. Institutional Review Board of Jimma University, School of Pharmacy approved the study (Reference, loH/SoP/723/2021). A letter of permission was received from the office of Chief Executive Officer of Jimma University Medical Center. The written informed consent of the study participants was taken prior to interviews for collection of data. The withdrawal right of study participants from involvements of study at any time was assured.

\section{Funding}

Not applicable.

\section{References}

1. World Health Organization. Legal Status of Traditional Medicine and Complementary/Alternative Medicine: A Worldwide Review. Geneva, Switzerland.https://apps.who.int/iris/handle/10665/42452 Accessed 09/2021. 
2. Bent S. Herbal medicine in the United States: Review of efficacy, safety, and regulation - Grand Rounds at University of California, San Francisco Medical Center. J Gen Intern Med. 2008;23(6):8549.

3. World Health Organization. WHO Traditional Medicine Strategy 2002-2005. WHO/EDM/TRM/20021, Geneva http://www.beovita.eu/pdf/WHO_EDM_TRM_2004.pdf.

4. Kifle ZD, Bayleyegn B, Yimer Tadesse T, Woldeyohanins AE. Prevalence and associated factors of herbal medicine use among adult diabetes mellitus patients at government hospital, Ethiopia: An institutional-based cross-sectional study. Metab Open [Internet]. 2021;11:100120. Available from: https://doi.org/10.1016/j.metop.2021.100120

5. Fong HHS. Integration of herbal medicine into modern medical practices: Issues and prospects. Integr Cancer Ther. 2002;1(3):287-93.

6. Clement $\mathrm{YN}$, Williams AF, Khan K, Bernard T, Bhola S, Fortuné $\mathrm{M}$, et al. A gap between acceptance and knowledge of herbal remedies by physicians: The need for educational intervention. BMC Complement Altern Med. 2005;5:1-9.

7. Kanjanahattakij N, Kwankhao P, Vathesatogkit P, Thongmung N, Gleebbua Y, Sritara P, et al. Herbal or traditional medicine consumption in a Thai worker population: Pattern of use and therapeutic control in chronic diseases. BMC Complement Altern Med. 2019;19(1):1-9.

8. Nsibirwa S, Anguzu G, Kamukama S, Ocama P, Nankya-Mutyoba J. Herbal medicine use among patients with viral and non-viral hepatitis in uganda: Prevalence, patterns and related factors. BMC Complement Med Ther. 2020;20(1):1-11.

9. D'Avigdor E, Wohlmuth H, Asfaw Z, Awas T. The current status of knowledge of herbal medicine and medicinal plants in Fiche, Ethiopia. J Ethnobiol Ethnomed. 2014;10(1):1-32.

10. Ekor M. The growing use of herbal medicines: Issues relating to adverse reactions and challenges in monitoring safety. Front Neurol. 2014;4 JAN(January):1-10.

11. Bandaranayake WM. Quality Control, Screening, Toxicity, and Regulation of Herbal Drugs. Modern Phytomedicine: Turning Medicinal Plants into Drugs. 2006. 25-57 p.

12. El-Dahiyat F, Rashrash M, Abuhamdah S, Abu Farha R, Babar ZUD. Herbal medicines: A crosssectional study to evaluate the prevalence and predictors of use among Jordanian adults. J Pharm Policy Pract. 2020;13(1):1-9.

13. Welz AN, Emberger-Klein A, Menrad K. The importance of herbal medicine use in the German healthcare system: Prevalence, usage pattern, and influencing factors. BMC Health Serv Res. 2019;19(1):111.

14. Clement YN, Morton-Gittens J, Basdeo L, Blades A, Francis MJ, Gomes N, et al. Perceived efficacy of herbal remedies by users accessing primary healthcare in Trinidad. BMC Complement Altern Med. 2007;7:1-9.

15. Meshesha SG, Yeshak MY, Gebretekle GB, Tilahun Z, Fenta TG. Concomitant Use of Herbal and Conventional Medicines among Patients with Diabetes Mellitus in Public Hospitals of Addis Ababa, Ethiopia: A Cross-Sectional Study. Evidence-based Complement Altern Med. 2020;2020. 
16. Nyeko R, Tumwesigye NM, Halage AA. Prevalence and factors associated with use of herbal medicines during pregnancy among women attending postnatal clinics in Gulu district, Northern Uganda. BMC Pregnancy Childbirth [Internet]. 2016;16(1):1-12. Available from: http://dx.doi.org/10.1186/s12884-016-1095-5

17. Rombolà L, Scuteri D, Marilisa S, Watanabe C, Morrone LA, Bagetta G, et al. Pharmacokinetic Interactions between Herbal Medicines and Drugs: Their Mechanisms and Clinical Relevance. Life (Basel, Switzerland). 2020 Jul;10(7).

18. Izzo AA, Di Carlo G, Borrelli F, Ernst E. Cardiovascular pharmacotherapy and herbal medicines: the risk of drug interaction. Int J Cardiol. 2005 Jan;98(1):1-14.

19. Fugh-Berman A. Herb-drug interactions. Lancet (London, England). 2000 Jan;355(9198):134-8.

20. Kiguba R, Ononge S, Karamagi C, Bird SM. Herbal medicine use and linked suspected adverse drug reactions in a prospective cohort of Ugandan inpatients. BMC Complement Altern Med [Internet]. 2016;16(1):1-8. Available from: http://dx.doi.org/10.1186/s12906-016-1125-x

21. Kiguba R, Karamagi C, Bird SM. Incidence, risk factors and risk prediction of hospital-acquired suspected adverse drug reactions : a prospective cohort of Ugandan inpatients. 2017;1-11.

22. Harnarayan P, Budhooram S. Adverse events in diabetic foot infections: a case control study comparing early versus delayed medical treatment after home remedies. 2014;239-43.

23. Auerbach BJ, Reynolds SJ, Lamorde M, Merry C, Kukunda-Byobona C, Ocama P, et al. Traditional herbal medicine use associated with liver fibrosis in rural Rakai, Uganda. PLoS One. 2012;7(11):e41737.

24. Mekuria AB, Belachew SA, Tegegn HG, Ali DS, Netere AK, Lemlemu E, et al. Prevalence and correlates of herbal medicine use among type 2 diabetic patients in Teaching Hospital in Ethiopia: a crosssectional study. 2018;1-8.

25. Werneke U, Earl J, Seydel C, Horn O, Crichton P, Fannon D. Potential health risks of complementary alternative medicines in cancer patients. Br J Cancer. 2004 Jan;90(2):408-13.

26. Fasinu PS, Bouic PJ, Rosenkranz B. An overview of the evidence and mechanisms of herb-drug interactions. Front Pharmacol. 2012;3 APR(April):1-19.

27. Bhamra SK, Slater A, Howard C, Heinrich M, Johnson MRD. Health care professionals' personal and professional views of herbal medicines in the United Kingdom. Phytother Res. 2019 Sep;33(9):23608.

28. Grauer RP, Thomas RD, Tronson MD, Heards GC, Diacon M. Preoperative use of herbal medicines and vitamin supplements. Anaesth Intensive Care. 2004;32(2):173-7.

29. Kilper A, Müller A, Huber R, Reimers N, Schütz L, Lederer AK. Complementary medicine in orthopaedic and trauma surgery: A cross-sectional survey on usage and needs. BMJ Open. 2020;10(9).

30. Abebe W. An overview of herbal supplement utilization with particular emphasis on possible interactions with dental drugs and oral manifestations. J Dent Hyg JDH. 2003;77(1):37-46.

31. Parvez MK, Rishi V. Herb-Drug Interactions and Hepatotoxicity. Curr Drug Metab. 2019;20(4):275-82. 
32. Aragaw TJ, Afework DT, Getahun KA. Assessment of Knowledge, Attitude, and Utilization of Traditional Medicine among the Communities of Debre Tabor Town, Amhara Regional State, North Central Ethiopia: A Cross-Sectional Study. Evidence-based Complement Altern Med. 2020;2020.

33. Laelago T, Yohannes T, Lemango F. Prevalence of herbal medicine use and associated factors among pregnant women attending antenatal care at public health facilities in Hossana Town, Southern Ethiopia: facility based cross sectional study. Arch Public Health. 2016;74:7.

34. Haile KT, Ayele AA, Mekuria AB, Demeke CA, Gebresillassie BM, Erku DA. Traditional herbal medicine use among people living with HIV/AIDS in Gondar, Ethiopia: Do their health care providers know? Complement Ther Med [Internet]. 2017;35(May):14-9. Available from: http://dx.doi.org/10.1016/j.ctim.2017.08.019

35. Hasen G, Hashim R. Current awareness of health professionals on the safety of herbal medicine and associated factors in the south west of ethiopia. J Multidiscip Healthc. 2021;14:2001-8.

36. Suleman S, Tufa TB, Kebebe D, Belew S, Mekonnen Y, Gashe F, et al. Treatment of Malaria and Related Symptoms Using Traditional Herbal Medicine in Ethiopia. J Ethnopharmacol [Internet]. 2017; Available from: https://doi.org/10.1016/j.jep.2017.10.034

37. Jimma University. Available from: https://www.ju.edu.et/?q=article/ specialized-hospital. Accessed August, 2021.

38. Raosoft ${ }^{\circledR}$ Sample Size Calculator. http://www.raosoft.com/samplesize.html. Accessed April,. 2020;

39. Hasen G, Negeso B. Patients satisfaction with pharmaceutical care and associated factors in the southwestern Ethiopia. Patient Prefer Adherence. 2021;15:2155-63.

40. Adane F, Seyoum G, Alamneh YM, Abie W, Desta M, Sisay B. Herbal medicine use and predictors among pregnant women attending antenatal care in Ethiopia: a systematic review and metaanalysis. 2020;8:1-11.

41. Revol B, Gautier-Veyret E, Arrivé C, Fouilhé Sam-Laï N, McLeer-Florin A, Pluchart H, et al. Pharmacokinetic herb-drug interaction between ginger and crizotinib. $\mathrm{Br} \mathrm{J}$ Clin Pharmacol. 2020;86(9):1892-3.

42. Ahad A, Raish M, Bin Jardan YA, Alam MA, Al-Mohizea AM, Al-Jenoobi Fl. Effect of Hibiscus sabdariffa and Zingiber officinale on the antihypertensive activity and pharmacokinetic of losartan in hypertensive rats. Xenobiotica [Internet]. 2020 Jul 2;50(7):847-57. Available from: https://doi.org/10.1080/00498254.2020.1729446

43. Quílez AM, Saenz MT, García Giménez MD. Uncaria tomentosa (Willd. ex. Roem. \& Schult.) DC. and Eucalyptus globulus Labill. interactions when administered with diazepam. Phyther Res. 2012;26(3):458-61.

44. González-Trujano ME, Urbina-Trejo E, Santos-Valencia F, Villasana-Salazar B, Carmona-Aparicio L, Martínez-Vargas D. Pharmacological and toxicological effects of Ruta chalepensis L. on experimentally induced seizures and electroencephalographic spectral power in mice. J Ethnopharmacol. 2021;271(May 2020). 
45. Lim XY, Chan JSW, Japri N, Lee JC, Tan TYC. Carica papaya L. Leaf: A Systematic Scoping Review on Biological Safety and Herb-Drug Interactions. Evidence-based Complement Altern Med. $2021 ; 2021$.

46. Deyno S, Abebe A, Tola MA, Hymete A, Bazira J, Makonnen E, et al. Acute and sub-acute toxicity of Echinops kebericho decoction in rats. BMC Complement Med Ther. 2020;20(1):1-11.

47. Schieman C, Rudmik LR, Dixon E, Sutherland F, Bathe OF. Complementary and alternative medicine use among general surgery, hepatobiliary surgery and surgical oncology patients. Can J Surg. 2009;52(5):422-6.

48. Critchley LAH, Chen DQ, Lee A, Thomas GN, Tomlinson B. A survey of Chinese herbal medicine intake amongst preoperative patients in Hong Kong. Anaesth Intensive Care. 2005;33(4):506-13.

49. Rashrash M, Schommer JC, Brown LM. Prevalence and Predictors of Herbal Medicine Use Among Adults in the United States. 2017;4(3):108-13.

\section{Figures}

\section{Prehospital use of herbal medicine}

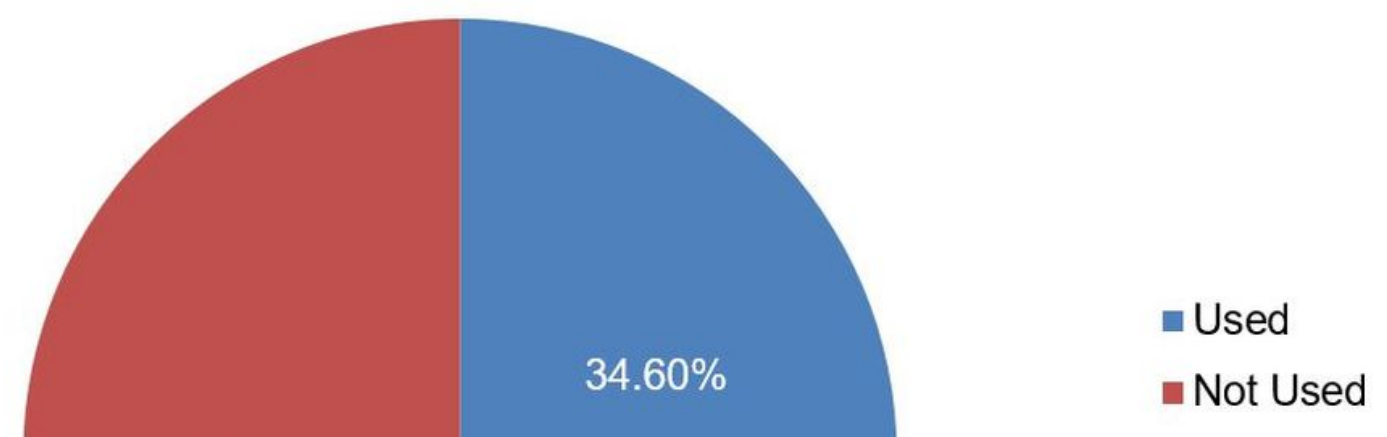

$65.40 \%$

\section{Figure 1}

The prevalence of prehospital use of herbal medicine 